\title{
Vitamin D dose response is underestimated by Endocrine Society's Clinical Practice Guideline
}

\author{
Malachi J McKenna ${ }^{1,2,3}$ and Barbara F Murray ${ }^{1}$ \\ ${ }^{1}$ St Michael's Hospital, Dún Laoghaire, Dublin, Ireland \\ ${ }^{2}$ Metabolism Laboratory, St Vincent's University Hospital, Dublin, Ireland \\ ${ }^{3}$ School of Medicine and Medical Sciences, University College Dublin, Dublin, Ireland
}

Correspondence

should be addressed

to M J McKenna

Email

mjmckenn@iol.ie

\begin{abstract}
Objective: The recommended daily intakes of vitamin D according to the recent Clinical Practice Guideline (CPG) of the Endocrine Society are three- to fivefold higher than the Institute of Medicine (IOM) report. We speculated that these differences could be explained by different mathematical approaches to the vitamin $D$ dose response.

Methods: Studies were selected if the daily dose was $\leq 2000$ IU/day, the duration exceeded 3 months, and 25-hydroxyvitamin D (25OHD) concentrations were measured at baseline and post-therapy. The rate constant was estimated according to the CPG approach. The achieved $250 \mathrm{HD}$ result was estimated according to the following: i) the regression equation approach of the IOM; ii) the regression approach of the Vitamin D Supplementation in Older Subjects (ViDOS) study; and iii) the CPG approach using a rate constant of 2.5 (CPG2.5) and a rate constant of 5.0 (CPG5.0). The difference between the expected and the observed 25OHD result was expressed as a percentage of observed and analyzed for significance against a value of $0 \%$ for the four groups.

Results: Forty-one studies were analyzed. The mean $(95 \% \mathrm{Cl})$ rate constant was 5.3 (4.4-6.2) nmol/l per $100 \mathrm{IU}$ per day, on average twofold higher than the CPG rate constant.

The mean $(95 \% \mathrm{Cl})$ for the difference between the expected and observed expressed as a percentage of observed was as follows: i) IOM, $-7(-16,+2) \%(t=1.64, P=0.110)$; ii) ViDOS, $+2(-8,+12) \%(t=0.40, P=0.69)$; iii) CPG2.5, $-21(-27,-15) \%(t=7.2, P<0.0001)$; and iv) CPG5.0+3 $(-4,+10) \%(t=0.91, P=0.366)$.

Conclusion: The CPG 'rule of thumb' should be doubled to $5.0 \mathrm{nmol} / \mathrm{l}(2.0 \mathrm{ng} / \mathrm{ml})$ per $100 \mathrm{IU}$ per day, adopting a more risk-averse position.
\end{abstract}

\author{
Key Words \\ - vitamin D dose response \\ - Institute of Medicine \\ - Endocrine Society's Clinical \\ Practice Guideline
}

Endocrine Connections (2013) 2, 87-95

\section{Introduction}

Two conflicting reports on vitamin $\mathrm{D}$ intake requirements were published in 2011: Institute of Medicine (IOM) report on Dietary Reference Intakes for Calcium and Vitamin D and the Endocrine Society's Clinical Practice Guideline (CPG) on Evaluation, Treatment, and Prevention of Vitamin D Deficiency $(1,2)$. The IOM, on behalf of the USA and Canadian governments, was tasked to review data on calcium and vitamin D intake requirements and their roles

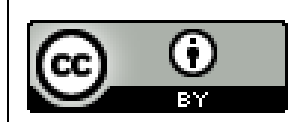


in human health (1). The CPG set its objective to provide guidelines to clinicians with a particular emphasis on the care of patients who are at risk for deficiency (2).

IOM specifies an estimated average requirement (EAR) of $400 \mathrm{IU} /$ day for those with minimal or no sunlight exposure - namely, those at risk of privational vitamin D deficiency $(3,4,5)$. CPG recommends an intake for those deemed to be at risk that is three- to fivefold higher at 1500-2000 IU/day without any specification about sunlight exposure $(2,6)$. CPG considers conditions of risk of vitamin D deficiency in need of augmented intakes, but IOM considers that these individuals are at increased risk if sun deprived and are therefore within the realm of the IOM specifications (5). IOM demonstrated that the evidence of benefit plateaus at $30-40 \mathrm{nmol} / \mathrm{l}$ $(12-16 \mathrm{ng} / \mathrm{ml})$ and covers the majority at $50 \mathrm{nmol} / \mathrm{l}$ (20 ng/ml). CPG claims a 25-hydroxyvitamin D (25OHD) threshold of $75 \mathrm{nmol} / \mathrm{l}(30 \mathrm{ng} / \mathrm{ml})$ as necessary for bone health. Conceptually, IOM deems a $25 \mathrm{OHD}$ concentration as a measure of risk of skeletal disease, but CPG deems a $25 \mathrm{OHD}$ concentration as diagnostic of 'deficiency' or 'insufficiency'. Operationally, IOM specifies that there is a distribution of requirements called the dietary reference intakes that correspond to 25OHD concentrations: the EAR, which corresponds to $40 \mathrm{nmol} / 1$ $(16 \mathrm{ng} / \mathrm{ml})$, meets the needs of $50 \%$ of the population and the recommended daily allowance, which corresponds to $50 \mathrm{nmol} / 1(20 \mathrm{ng} / \mathrm{ml})$, meets the needs of all but $97.5 \%$ of the population $(1,4,7)$. CPG designates $75 \mathrm{nmol} / \mathrm{l}(30 \mathrm{ng} / \mathrm{ml})$ as the optimal 25OHD concentration for all.

According to the CPG, the vitamin D dose response is best described by a rate constant, or 'rule of thumb', whereby $25 \mathrm{OHD}$ is expected to increase by $2.5 \mathrm{nmol} / 1$ $(1 \mathrm{ng} / \mathrm{ml})$ for each $100 \mathrm{IU} /$ day of vitamin D ingested $(2,8)$. IOM noted a curvilinear response between vitamin D intake and $25 \mathrm{OHD}$ as follows: $25 \mathrm{OHD} \mathrm{nmol} / \mathrm{l}=9.9 \times \mathrm{ln}$ (total vitamin D intake (IU/day)). In a study of low-dose oral vitamin D intake (800 IU/day) administered to institutionalized elderly for 16 months with severe hypovitaminosis $\mathrm{D}$, we noted a dose-response of $9.1 \mathrm{nmol} / \mathrm{l}(3.6 \mathrm{ng} / \mathrm{ml})$ per $100 \mathrm{IU}$ per day, nearly fourfold higher than the CPG estimate $(9,10)$. Using the IOM regression equation, the predicted mean $25 \mathrm{OHD}$ for our study should have been $66 \mathrm{nmol} / 1(26 \mathrm{ng} / \mathrm{ml})$, which is similar to the observed mean value of $79 \mathrm{nmol} / \mathrm{l}$ (31.9 ng/ml) (10). We speculated that the CPG approach by underestimating the vitamin $\mathrm{D}$ dose response could be a reason for their higher intake specifications.

\section{Materials and methods}

We only selected studies that had been compiled from the three major reports on vitamin D: Agency for Health Research Quality (AHRQ)-Ottawa, Effectiveness and Safety of Vitamin D in Relation to Bone Health (11); AHRQ-Tufts, Vitamin D and Calcium: Systematic Review of Health Outcomes (12); and the IOM report (1). Studies were chosen in this way because all studies are described in detail, including a critical appraisal and a grading of quality $(1,11,12)$. Inclusion criteria for selection of studies were as follows: daily oral dose of vitamin $\mathrm{D}\left(\mathrm{D}_{2}\right.$ or $\left.\mathrm{D}_{3}\right)$ $\leq 2000$ IU/day; duration at least 3 months; and results of both baseline and post-therapy 25OHD concentrations.

The rate constant for each study was calculated and presented according to the CPG approach of nanomoles per litre rise in 25OHD per $100 \mathrm{IU} /$ day of vitamin D dose. The ratio of observed-to-expected rate constant for each study was calculated. The achieved $25 \mathrm{OHD}$ result was estimated according to i) the regression equation approach of the IOM; ii) the regression approach of Vitamin D Supplementation in Older Subjects (ViDOS) (25OHD $\mathrm{nmol} / \mathrm{l}=54.5+24.6 \times$ dose $/ 1000-2.5 \times$ dose $\left.^{2} / 1000^{2}\right)(13)$; and iii) the CPG approach using a rate constant of 2.5 (CPG2.5) and a rate constant of 5.0 (CPG5.0). The difference between the expected $(E)$ and observed $(O)$ was expressed as a percentage of observed and was calculated as follows for each study: $((E-O) / O) \times 100$.

Descriptive statistics are presented as mean and 95\% CIs, as median and interquartile range (IQR), or as number and percentage. A one-sample $t$-test was performed to test whether mean differences, as calculated earlier, were different from $0 \%$ for each of the four groups. Statistics were performed using IBM SPSS Stats for Windows Version 20.

\section{Results}

Forty-one studies met the selection criteria (Table 1) $(14,15,16,17,18,19,20,21,22,23,24,25,26,27,28$, $29,30,31,32,33,34,35,36,37,38,39,40,41,42,43,44$, $45,46,47,48,49,50,51,52)$. Studies included young adults $(n=3)$, community-dwelling older adults $(n=22)$, and institutionalized elderly adults $(n=16)$. The majority $(n=36)$ were obtained from AHRQ-Ottawa, and 5 were identified from AHRQ-Tufts (16, 17, 18, 20, 52). No additional study was identified in IOM, excluding those studies that were used for the simulated vitamin D dose response. Six studies had two subgroups that were given exactly the same dose; averages of the baseline and posttherapy 25OHD concentrations were calculated rather

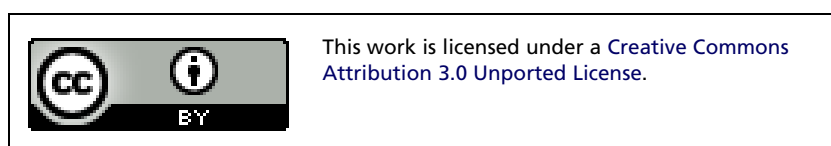




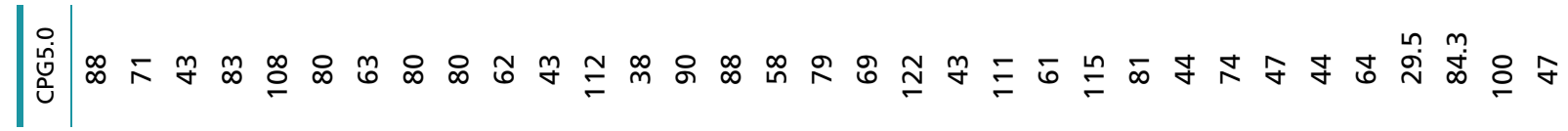

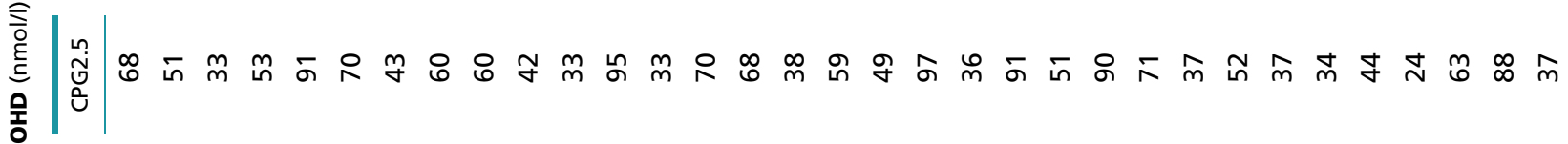
离离 은

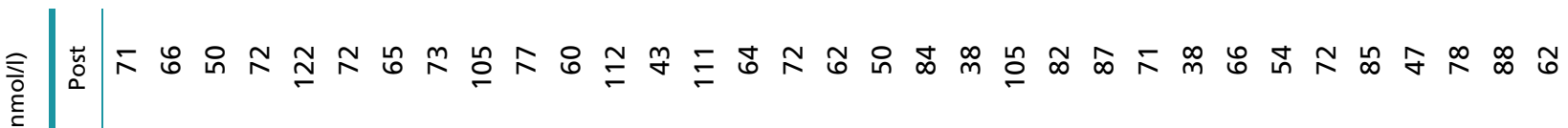

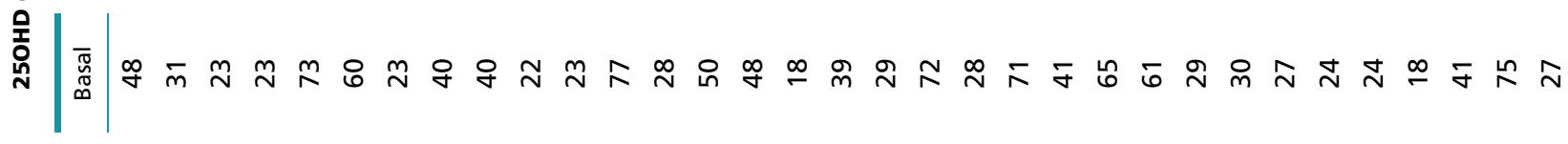

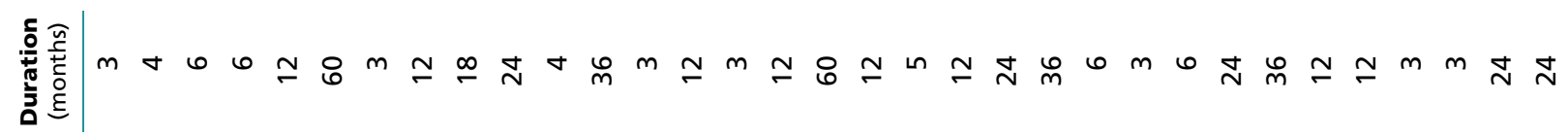
茖离|

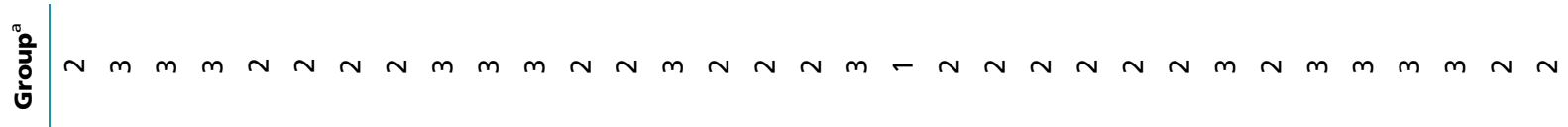

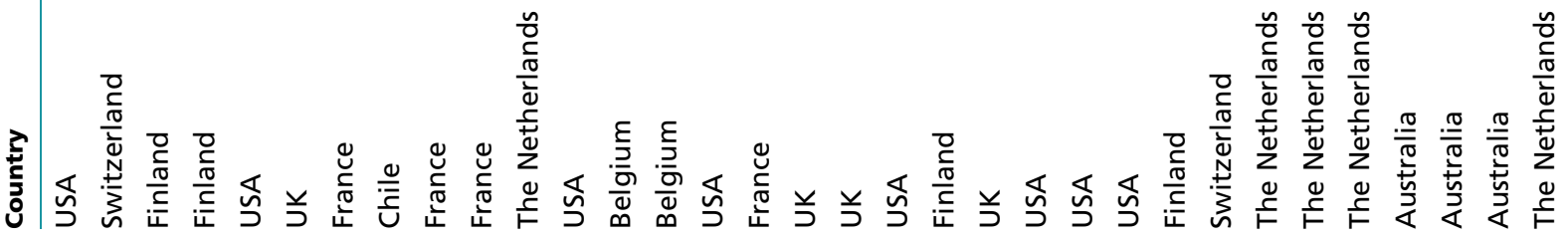

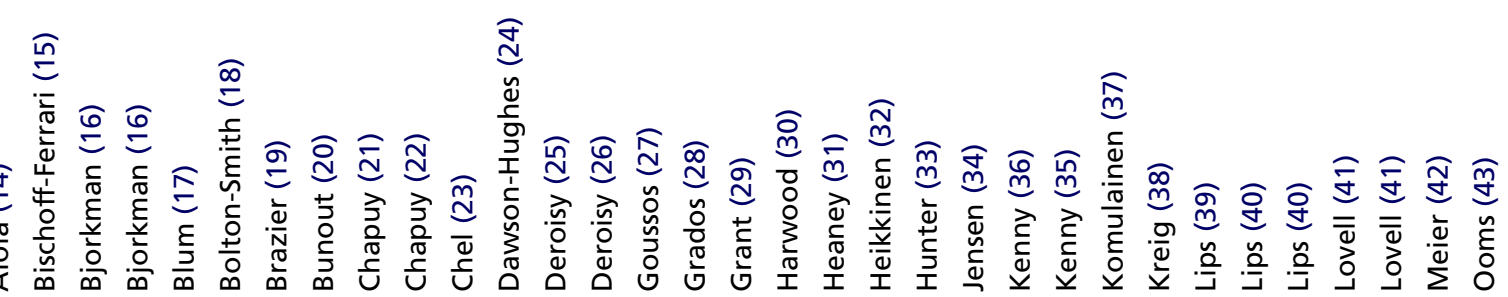




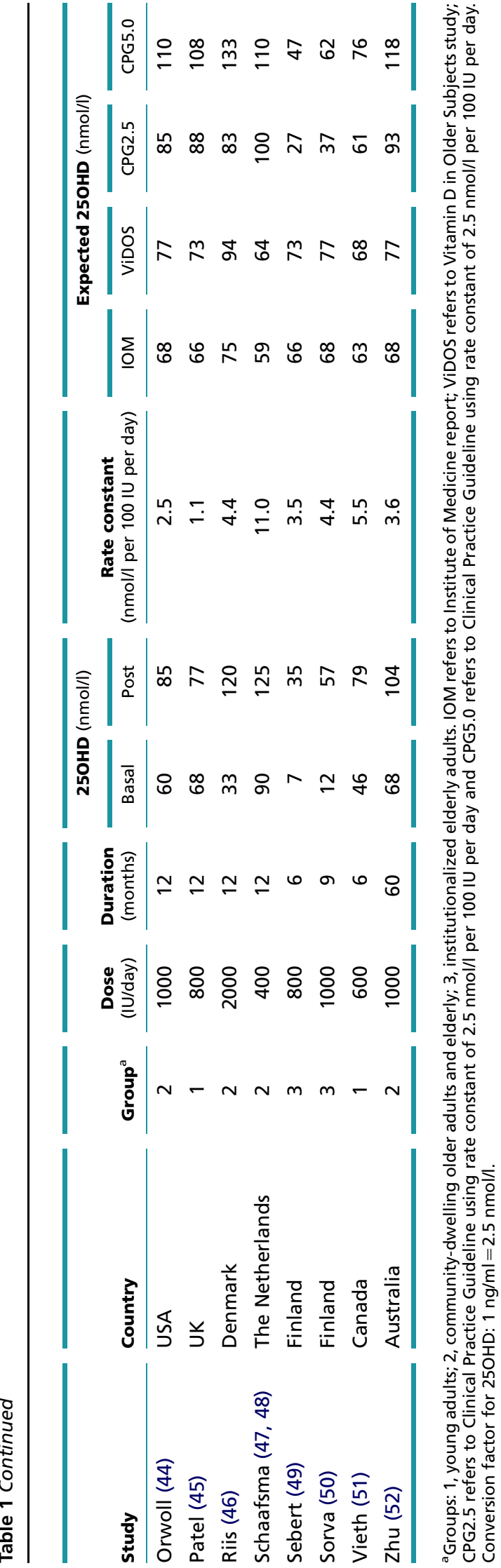

http://www.endocrineconnections.org DOI: 10.1530/EC-13-0008

2013 The authors Published by Bioscientifica Ltd than have duplicate entries $(24,26,34,35,48,50)$. Thirtythree of the studies were randomized control studies regarding the effect of vitamin $\mathrm{D}$ supplementation on 25OHD concentrations.

The median (minimum-maximum) dose was 800 (200-2000) IU/day. The median (minimum-maximum) duration of treatment was 12 (3-60) months. The isoform of administered vitamin $\mathrm{D}$ was vitamin $\mathrm{D}_{2}(n=1)$, vitamin $\mathrm{D}_{3}(n=33)$, and not specified $(n=7)$. The median (IQR) 25OHD concentration pre-therapy was 39 (24-61) nmol/1 (16 (10-24) $\mathrm{ng} / \mathrm{ml})$ and post-therapy was 72 (61-86) $\mathrm{nmol} / \mathrm{l}(29$ (24-34) ng/ml).

The mean (95\% CI) rate constant was $5.3(4.4-6.2)$ $\mathrm{nmol} / \mathrm{l}$ per $100 \mathrm{IU}$ per day ranging from 1.1 to $12.6 \mathrm{nmol} / 1$ per $100 \mathrm{IU}$ per day (Fig. 1). The mean (95\% CI) for the observed:expected ratio of the rate constants with respect to the CPG rate constant of $2.5 \mathrm{nmol} / 1$ per $100 \mathrm{IU}$ per day was $2.1(1.7-2.5)$. The mean $(95 \% \mathrm{CI})$ for the difference between the expected and observed expressed as a percentage of observed with the result of the one-sample $t$-tests was as follows: i) for IOM $-7(-16,+2) \%(t=1.64$, $P=0.110)$; ii) for ViDOS $+2(-8,+12) \% \quad(t=0.40$, $P=0.69)$; iii) for CPG using rate constant of 2.5 was -21 $(-27,-15) \%(t=7.2, P<0.0001)$; and iv) for CPG using rate constant of 5.0 was $+3(-4,+10) \% \quad(t=0.91$, $P=0.366$ ) (Fig. 2).

\section{Discussion}

The CPG approach is an easy-to-remember 'rule of thumb' whereby the clinician calculates the difference between a patient's 25OHD result and the CPG target of $75 \mathrm{nmol} / 1$ $(30 \mathrm{ng} / \mathrm{ml})$, then divides that difference by their rate constant of 2.5 , and finally multiples the answer by 100 to estimate the required vitamin $\mathrm{D}$ dose $(2,8)$. According to the findings of our report, this CPG rate constant on average underestimates the rate constant by twofold. The reason for the substantial underestimate is explained by the dose-response curve for vitamin D. Both IOM and ViDOS noted a curvilinear dose-response curve. The CPG rate constant is principally influenced by a dose-response study in which the baseline 25OHD concentration $\sim 70 \mathrm{nmol} / \mathrm{l}(28.0 \mathrm{ng} / \mathrm{ml})$ and three high-dose vitamin D schedules were administered, namely 1000, 5000, and 10000 IU/day (31). When the IOM was deliberating on its approach to vitamin D dose response, it reviewed previous attempts at estimating a rate constant $(11,31)$. IOM noted that lower intakes had a greater response, but they also concluded that if an individual was already taking $1000 \mathrm{IU} /$ day, then the rate constant would be

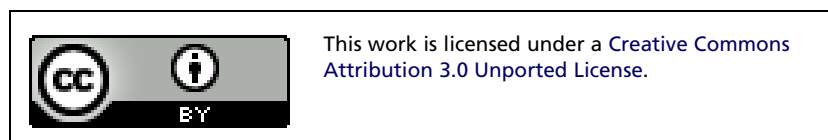




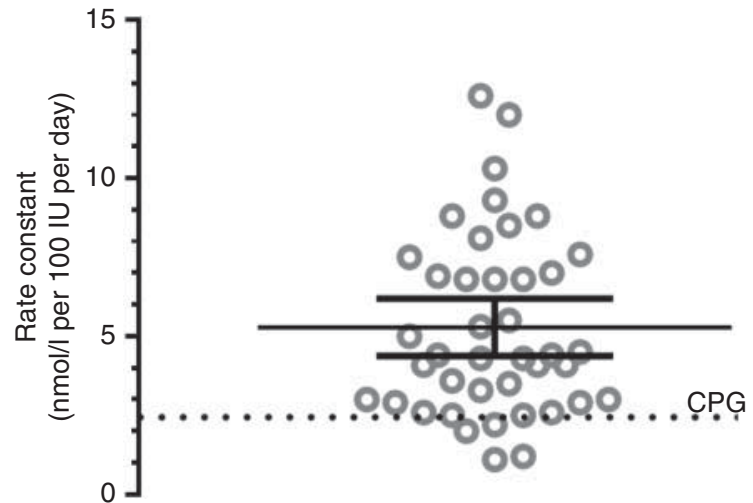

\section{Figure 1}

This plot depicts rate constants in the 41 studies. The mean $(95 \% \mathrm{Cl})$ is 5.3 (4.4-6.2) rise of 25OHD nmol/l per vitamin D intake of $100 \mathrm{IU} / \mathrm{day}$. The Clinical Practice Guideline (CPG) rate constant of $2.5 \mathrm{nmol} / \mathrm{l}$ per 100 IU per day is depicted by the broken line.

$\sim 2.5 \mathrm{nmol} / 1(1.0 \mathrm{ng} / \mathrm{ml})$ per $100 \mathrm{IU}$ per day. Another important factor is the degree of hypovitaminosis $\mathrm{D}$ : the lower the 25OHD concentration, the greater the response. So the current CPG rate constant should only give an accurate estimate in circumstances when the baseline concentration of $25 \mathrm{OHD}$ exceeds $70 \mathrm{nmol} / 1(28.0 \mathrm{ng} / \mathrm{ml})$ and the intake exceeds $1000 \mathrm{IU} /$ day. Regarding other confounders of the dose-response, the ViDOS study demonstrated that BMI was a confounder with 25OHD response being attenuated by increased BMI; also there was an interaction effect between BMI and time (13). Other covariates had no effect such as age, calcium intake, smoking status, alcohol use, average caffeine intake, and serum creatinine. The IOM report also excluded an interaction effect with age over a broader age range from childhood to the elderly (1).

While we demonstrated a very high rate constant in our study of institutionalized patients at $9.1 \mathrm{nmol} / \mathrm{l}$ $(3.6 \mathrm{ng} / \mathrm{ml})$ per $100 \mathrm{IU}$ per day, in a subsequent systematic review of published literature up to 1995, we suggested that the average rate constant was $5.5 \mathrm{nmol} / \mathrm{l}(2.2 \mathrm{ng} / \mathrm{ml})$ per $100 \mathrm{IU}$ per day, which is remarkably similar to the current observation (53). This fact had been noted and discussed by the authors of the study that formed the basis of the CPG rate constant (31). The current finding regarding the rate constant is supported by a metaregression analysis of randomized control trials of vitamin D supplementation $(n=51)$ that has just be published in abstract form (54). The authors noted a mean increase of $48 \mathrm{nmol} / 1(19.2 \mathrm{ng} / \mathrm{ml})$ with a daily dose of $800 \mathrm{IU} /$ day after 6 months that is equivalent to a rate constant of $6 \mathrm{nmol} / \mathrm{l}(2.4 \mathrm{ng} / \mathrm{ml})$ per $100 \mathrm{IU}$ per day.
Similarly, in a recent systematic review, Autier et al. (55) estimated that an intake of $800 \mathrm{IU} /$ day combined with calcium in those with a mean $25 \mathrm{OHD}$ level of $25 \mathrm{nmol} / \mathrm{l}$ should elevate the level on average by $36 \mathrm{nmol} / \mathrm{l}$, which is equivalent to a rate constant of $4 \mathrm{nmol} / \mathrm{l}(1.6 \mathrm{ng} / \mathrm{ml})$ per 100 IU per day.

The regression approach, as used by IOM and ViDOS, is much more satisfactory. Both recommend that one should attempt to estimate the target 25OHD concentration based on either total daily oral vitamin $\mathrm{D}$ intake according to IOM or on dose administered according to ViDOS. The average observed 25OHD concentration was within the confidence limits according to the 25OHD concentration estimated by both the IOM and ViDOS equations, although the 95\% CIs are large. The IOM regression equation slightly underestimates the achieved 25OHD concentration, but this is not unexpected as the IOM regression equation is based on total vitamin $D$ intake and the studies only provided information on vitamin $\mathrm{D}$ dose, thus underestimating the total oral vitamin D intake. Regarding a similar analysis of the CPG approach, if a rate constant of $5.0 \mathrm{nmol} / 1(2.0 \mathrm{ng} / \mathrm{ml})$ per $100 \mathrm{IU}$ per day is chosen instead of a rate constant of $2.5 \mathrm{nmol} / 1$ $(1.0 \mathrm{ng} / \mathrm{ml})$ per $100 \mathrm{IU}$ per day, then the CPG approach is as good at estimating the $25 \mathrm{OHD}$ achieved concentration as both IOM and ViDOS (Fig. 2).

While classical toxicity occurs at $25 \mathrm{OHD}$ concentrations above $250 \mathrm{nmol} / \mathrm{l}(100 \mathrm{ng} / \mathrm{ml})(2)$, there are concerns about harm at much lower concentrations $(1,56)$. There are

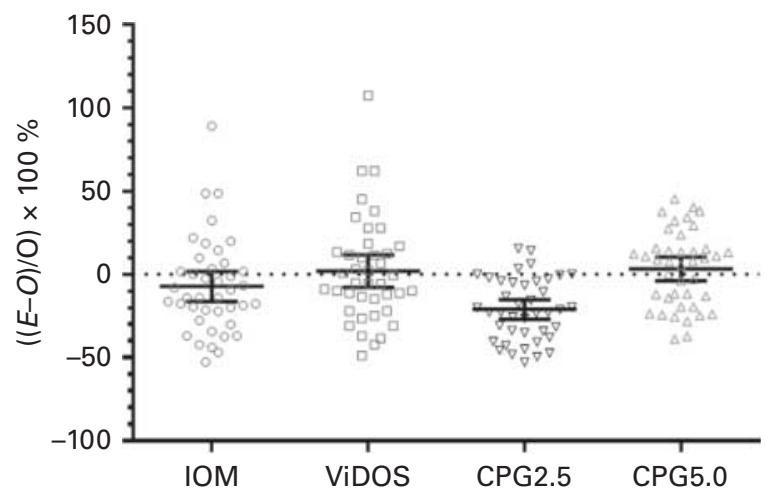

\section{Figure 2}

This plot depicts differences between the expected and observed expressed as a percentage of observed in the 41 studies. The mean and $95 \% \mathrm{Cls}$ are represented by continuous lines. IOM refers to Institute of Medicine report; ViDOS refers to Vitamin D in Older Subjects study; CPG2.5 refers to Clinical Practice Guideline using rate constant of $2.5 \mathrm{nmol} / \mathrm{l}$ per $100 \mathrm{IU}$ per day; and CPG5.0 refers to Clinical Practice Guideline using rate constant of $5.0 \mathrm{nmol} / \mathrm{l}$ per $100 \mathrm{IU}$ day. E, expected 25OHD; O, observed 25OHD.

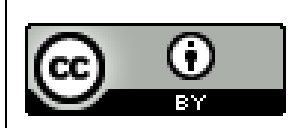


emerging concerns about risks at serum $25 \mathrm{OHD}$ concentrations above $125 \mathrm{nmol} / \mathrm{l}(50 \mathrm{ng} / \mathrm{ml})(1,3)$. There is a substantial safety window between $50 \mathrm{nmol} / \mathrm{l}(20 \mathrm{ng} / \mathrm{ml})$ and $125 \mathrm{nmol} / \mathrm{l}(50 \mathrm{ng} / \mathrm{ml})$. There are now five reasons why the Endocrine Society's CPG could lead to either unnecessary overreplacement for many or hypervitaminosis D with potential harm for some: i) labeling patients as 'deficient' or 'insufficient' rather than viewing a 25OHD concentration as a measure of risk, thus heightening concern; ii) setting a higher threshold for 25OHD at $75 \mathrm{nmol} / 1 \quad(30 \mathrm{ng} / \mathrm{ml})$ compared with $50 \mathrm{nmol} / 1$ (20 ng/ml) for IOM; iii) advising that all have 25OHD concentrations above the threshold of $75 \mathrm{nmol} / 1$ (30 $\mathrm{ng} / \mathrm{ml})$, instead of considering that there is a range of requirements like $\mathrm{IOM}$, which specifies that a concentration above $40 \mathrm{nmol} / \mathrm{l}(16 \mathrm{ng} / \mathrm{ml})$ meets the needs of 50\% of the population according to a probabilistic model (7); iv) failing to distinguish between those 'at risk' for privational hypovitaminosis $\mathrm{D}$, whose intake requirements are covered by IOM specifications, and those 'at risk' for disease-specific reasons; v) and underestimating the rate constant by twofold that is likely to overestimate the intake requirements in those whose concentrations are below $70 \mathrm{nmol} / \mathrm{l}(28.0 \mathrm{ng} / \mathrm{ml})$ and whose intakes are below $1000 \mathrm{IU} /$ day.

One example whereby CPG may lead to toxicity is in infancy. CPG recommends intakes of 400-1000 IU/day for all infants, and $2000 \mathrm{IU} /$ day for 6 weeks for those with concentrations below $50 \mathrm{nmol} / \mathrm{l}(20 \mathrm{ng} / \mathrm{ml})$ (2). IOM, due to lack of evidence, only specifies an 'adequate intake' of $400 \mathrm{IU} /$ day, which is likely to meet the needs of the majority (1). In a recent survey of preterm infants with $25 \mathrm{OHD}$ concentrations $<50 \mathrm{nmol} / \mathrm{l}(20.0 \mathrm{ng} / \mathrm{ml})$ who were followed into infancy at about 3-4 months, we observed that an intake of $400 \mathrm{IU} /$ day from feeds and supplements yielded an average 25OHD concentration of $83 \mathrm{nmol} / \mathrm{l}$ (33 ng/ml). Nearly 10\% had concentrations above $125 \mathrm{nmol} / \mathrm{l}(50 \mathrm{ng} / \mathrm{ml})$, and one infant had a $188 \mathrm{nmol} / 1(75 \mathrm{ng} / \mathrm{ml})$ who was actually ingesting $850 \mathrm{IU} /$ day, which is within the CPG recommendation (57). There is a recent case series of infants with hypercalcemia highlighting the problem of oversupplementation (58). Infants are most at risk of vitamin D toxicity due to mutations in the vitamin D-metabolizing enzyme CYP24A1 that increases sensitivity to oral vitamin D (59).

IOM has shifted the paradigm from thinking about 'more is better' to a more risk-averse approach (3). It has also challenged the notion that harm should just be viewed in terms of vitamin $\mathrm{D}$ toxicity such as hypercalcemia, hypercalciuria, or metastatic calcification. It has advanced the concept of 'harm' in terms of chronic disease outcomes and mortality (1). This viewpoint is further enhanced by more recent reports on links with allcause mortality and with prostate cancer $(56,60)$. Empiric evidence requires demonstration of harm in the setting of a randomized clinical trial. It may be some time before such evidence is forthcoming, but a recent report from Australia is informative. In a randomized trial of annual high-dose oral vitamin $\mathrm{D}$ that had falls and fractures as outcome measures, intervention resulted in increased risk of falls and fractures; in a small sample of the treated group, 25OHD levels reached an average concentration of $120 \mathrm{nmol} / \mathrm{l}$ that approximates the upper safe level specified by IOM. It is more risk averse to adopt a stochastic approach of harm rather than a deterministic approach of toxicity.

A limitation of this paper is that original studies were not reviewed by us, but instead the data were extracted from three major reports. In deference to the AHRQ and IOM process, it would not have been possible to emulate the work of the Evidence-based Practice Centers that assimilated nearly 40 years of clinical studies on vitamin D, informing their comprehensive assessments. Furthermore, this paper was not designed as a meta-regression analysis. In fact, it started as a clinical observation that the Endocrine Society's approach to vitamin D dose response was far removed from our clinical and research observations and was also inclined substantially toward underestimating the vitamin D response. Another limitation of this study is comparing reports that use different models of the vitamin D dose response: a linear model with two curvilinear models.

It seems prudent to probe the boundaries of benefit by augmenting vitamin $\mathrm{D}$ intake to higher levels in carefully conducted research studies, but clinical practice and clinical guidelines need not leap ahead of the evidence as presented in recent reports from AHRQ, IOM, and the US Preventative Services Task Force (1, 11, $12,61,62)$. The way forward is the implementation of IOM recommendations, worldwide, especially given that the new specifications have increased two- to threefold for children and young adults and increased by 33-50\% for those over age 50 years compared with the last IOM report in 1997 (63). We conclude that the CPG advice regarding vitamin D dose to patients overestimates the rate constant by twofold on average. We suggest that the 'rule of thumb' of the CPG, if it is to be used, should be doubled to $5.0 \mathrm{nmol} / \mathrm{l}(2.0 \mathrm{ng} / \mathrm{ml})$ per $100 \mathrm{IU}$ per day. This would be more reliable as well as being a more risk-averse approach.

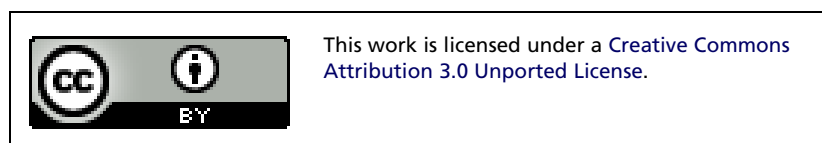




\section{Declaration of interest}

The authors declare that there is no conflict of interest that could be perceived as prejudicing the impartiality of the research reported.

\section{Funding}

This research did not receive any specific grant from any funding agency in the public, commercial or not-for-profit sector.

\section{Author contribution statement}

The authors' responsibilities were as follows: M J McKenna conceived the study, analyzed the data, and performed the statistical analyses; M J McKenna and B F Murray wrote the manuscript. Both authors read and approved the final manuscript.

\section{Acknowledgements}

Presented in oral form at the Annual Meeting of the American Society of Bone and Mineral Research, Minneapolis, October 2012.

\section{References}

1 Committee to Review Dietary Reference Intakes for Vitamin D and Calcium \& Institute of Medicine. Dietary Reference Intakes for Calcium and Vitamin D. The National Academies Press, 2011.

2 Holick MF, Binkley NC, Bischoff-Ferrari HA, Gordon CM, Hanley DA, Heaney RP, Murad MH \& Weaver CM. Evaluation, treatment, and prevention of vitamin D deficiency: an Endocrine Society Clinical Practice Guideline. Journal of Clinical Endocrinology and Metabolism 2011 96 1191-1930. (doi:10.1210/jc.2011-0385)

3 Ross AC, Manson JE, Abrams SA, Aloia JF, Brannon PM, Clinton SK, Durazo-Arvizu RA, Gallagher JC, Gallo RL, Jones G et al. The 2011 report on dietary reference intakes for calcium and vitamin $\mathrm{D}$ from the Institute of Medicine: what clinicians need to know. Journal of Clinical Endocrinology and Metabolism 201196 53-58. (doi:10.1210/ jc.2010-2704)

4 Aloia JF. The 2011 report on dietary reference intake for vitamin D: where do we go from here? Journal of Clinical Endocrinology and Metabolism 201196 2987-2996. (doi:10.1210/jc.2011-0090)

5 Rosen CJ, Abrams SA, Aloia JF, Brannon PM, Clinton SK, Durazo-Arvizu RA, Gallagher JC, Gallo RL, Jones G, Kovacs CS et al. IOM committee members respond to endocrine society vitamin $\mathrm{D}$ guideline. Journal of Clinical Endocrinology and Metabolism 201297 1146-1152. (doi:10.1210/jc.2011-2218)

6 Holick MF, Binkley NC, Bischoff-Ferrari HA, Gordon CM, Hanley DA, Heaney RP, Murad MH \& Weaver CM. Guidelines for Preventing and Treating Vitamin D Deficiency and Insufficiency Revisited. Journal of Clinical Endocrinology and Metabolism 201297 1153-1158. (doi:10.1210/ jc.2011-2601)

7 Taylor CL, Carriquiry AL, Bailey RL, Sempos CT \& Yetley EA. Appropriateness of the probability approach with a nutrient status biomarker to assess population inadequacy: a study using vitamin D. American Journal of Clinical Nutrition 201397 72-78. (doi:10.3945/ ajcn.112.046094)

8 Heaney RP \& Holick MF. Why the IOM recommendations for vitamin D are deficient. Journal of Bone and Mineral Research 201126 455-457. (doi:10.1002/jbmr.328)

9 McKenna MJ, Freaney R, Meade A \& Muldowney FP. Hypovitaminosis D and elevated serum alkaline phosphatase in elderly Irish people. American Journal of Clinical Nutrition 198541 101-109.
10 McKenna MJ, Freaney R, Meade A \& Muldowney FP. Prevention of hypovitaminosis D in the elderly. Calcified Tissue International 198537 112-116. (doi:10.1007/BF02554828)

11 Cranney A, Horsley T, O’Donnell S, Weiler HA, Puil L, Ooi DS, Atkinson SA, Ward LM, Moher D, Hanley DA, et al. Effectiveness and safety of vitamin D in relation to bone health. Evidence report/ technology assessment no. 158. In AHRQ Publication No. 07-E013. Rockville, MD: Agency for Healthcare Research and Quality, 2007.

12 Chung M, Balk EM, Brendel M, Ip S, Lau J, Lee J, Lichtenstein A, Patel K, Raman G, Tatsioni A, et al. Vitamin D and calcium: systematic review of health outcomes. Evidence report/technology assessment no. 183. In AHRQ Publication No. 09-E015. Rockville, MD: Agency for Healthcare Research and Quality, 2009.

13 Gallagher JC, Sai A, Templin T II \& Smith L. Dose response to vitamin D supplementation in postmenopausal women: a randomized trial. Annals of Internal Medicine 2012156 425-437. (doi:10.1059/0003-4819. 156-6-201203200-00005)

14 Aloia JF, Talwar SA, Pollack S \& Yeh J. A randomized controlled trial of vitamin D3 supplementation in African American women. Archives of Internal Medicine 2005165 1618-1623. (doi:10.1001/ archinte.165.14.1618)

15 Bischoff-Ferrari HA, Conzelmann M, Dick W, Theiler R \& Stahelin HB. Effect of vitamin D on muscle strength and relevance in regard to osteoporosis prevention. Zeitschrift für Rheumatologie 200362 518-521. (doi:10.1007/s00393-003-0561-4)

16 Bjorkman M, Sorva A, Risteli J \& Tilvis R. Vitamin D supplementation has minor effects on parathyroid hormone and bone turnover markers in vitamin D-deficient bedridden older patients. Age and Ageing 200837 25-31. (doi:10.1093/ageing/afm141)

17 Blum M, Dallal GE \& Dawson-Hughes B. Body size and serum 25 hydroxy vitamin $\mathrm{D}$ response to oral supplements in healthy older adults. Journal of the American College of Nutrition 200827 274-279.

18 Bolton-Smith C, McMurdo ME, Paterson CR, Mole PA, Harvey JM, Fenton ST, Prynne CJ, Mishra GD \& Shearer MJ. Two-year randomized controlled trial of vitamin K1 (phylloquinone) and vitamin D3 plus calcium on the bone health of older women. Journal of Bone and Mineral Research 200722 509-519. (doi:10.1359/jbmr.070116)

19 Brazier M, Grados F, Kamel S, Mathieu M, Morel A, Maamer M, Sebert JL \& Fardellone P. Clinical and laboratory safety of one year's use of a combination calcium + vitamin D tablet in ambulatory elderly women with vitamin D insufficiency: results of a multicenter, randomized, double-blind, placebo-controlled study. Clinical Therapeutics 200527 1885-1893. (doi:10.1016/j.clinthera.2005.12.010)

20 Bunout D, Barrera G, Leiva L, Gattas V, de la Maza MP, Avendano M \& Hirsch S. Effects of vitamin D supplementation and exercise training on physical performance in Chilean vitamin D deficient elderly subjects. Experimental Gerontology 200641 746-752. (doi:10.1016/ j.exger.2006.05.001)

21 Chapuy MC, Arlot ME, Duboeuf F, Brun J, Crouzet B, Arnaud S, Delmas PD \& Meunier PJ. Vitamin D3 and calcium to prevent hip fractures in the elderly women. New England Journal of Medicine 1992 327 1637-1642. (doi:10.1056/NEJM199212033272305)

22 Chapuy MC, Pamphile R, Paris E, Kempf C, Schlichting M, Arnaud S, Garnero P \& Meunier PJ. Combined calcium and vitamin D3 supplementation in elderly women: confirmation of reversal of secondary hyperparathyroidism and hip fracture risk: the Decalyos II study. Osteoporosis International 200213 257-264. (doi:10.1007/ s001980200023)

23 Chel VG, Ooms ME, Popp-Snijders C, Pavel S, Schothorst AA, Meulemans CC \& Lips P. Ultraviolet irradiation corrects vitamin D deficiency and suppresses secondary hyperparathyroidism in the elderly. Journal of Bone and Mineral Research 199813 1238-1242. (doi:10.1359/jbmr.1998.13.8.1238)

24 Dawson-Hughes B, Harris SS, Krall EA \& Dallal GE. Effect of calcium and vitamin $\mathrm{D}$ supplementation on bone density in men and women 65

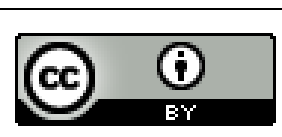


years of age or older. New England Journal of Medicine 1997337 670-676. (doi:10.1056/NEJM199709043371003)

25 Deroisy R, Collette J, Albert A, Jupsin I \& Reginster JY. Administration of a supplement containing both calcium and vitamin D is more effective than calcium alone to reduce secondary hyperparathyroidism in postmenopausal women with low $25(\mathrm{OH})$ vitamin D circulating levels. Aging Clinical and Experimental Research 200214 13-17.

26 Deroisy R, Collette J, Chevallier T, Breuil V \& Reginster JY. Effects of two 1-year calcium and vitamin D3 treatments on bone remodeling markers and femoral bone density in elderly women. Current Therapeutic Research 199859 850-862. (doi:10.1016/S0011-393X(98)85050-9)

27 Goussous R, Song L, Dallal GE \& Dawson-Hughes B. Lack of effect of calcium intake on the 25-hydroxyvitamin D response to oral vitamin D3. Journal of Clinical Endocrinology and Metabolism 200590 707-711. (doi:10.1210/jc.2004-1380)

28 Grados F, Brazier M, Kamel S, Duver S, Heurtebize N, Maamer M, Mathieu M, Garabedian M, Sebert JL \& Fardellone P. Effects on bone mineral density of calcium and vitamin D supplementation in elderly women with vitamin D deficiency. Joint, Bone, Spine 200370 203-208. (doi:10.1016/S1297-319X(03)00046-0)

29 Grant AM, Avenell A, Campbell MK, McDonald AM, MacLennan GS, McPherson GC, Anderson FH, Cooper C, Francis RM, Donaldson C et al. Oral vitamin D3 and calcium for secondary prevention of low-trauma fractures in elderly people (Randomised Evaluation of Calcium Or vitamin D, RECORD): a randomised placebo-controlled trial. Lancet 2005365 1621-1628. (doi:10.1016/S0140-6736(05)63013-9)

30 Harwood RH, Sahota O, Gaynor K, Masud T \& Hosking DJ. A randomised, controlled comparison of different calcium and vitamin D supplementation regimens in elderly women after hip fracture: The Nottingham Neck of Femur (NONOF) study. Age and Ageing 200433 45-51. (doi:10.1093/ageing/afh002)

31 Heaney RP, Davies KM, Chen TC, Holick MF \& Barger-Lux MJ. Human serum 25-hydroxycholecalciferol response to extended oral dosing with cholecalciferol. American Journal of Clinical Nutrition 2003 77 204-210.

32 Heikkinen A, Parviainen MT, Tuppurainen MT, Niskanen L, Komulainen MH \& Saarikoski S. Effects of postmenopausal hormone replacement therapy with and without vitamin D3 on circulating levels of 25-hydroxyvitamin D and 1,25-dihydroxyvitamin D. Calcified Tissue International 199862 26-30. (doi:10.1007/s002239900389)

33 Hunter D, Major P, Arden N, Swaminathan R, Andrew T, MacGregor AJ, Keen R, Snieder H \& Spector TD. A randomized controlled trial of vitamin D supplementation on preventing postmenopausal bone loss and modifying bone metabolism using identical twin pairs. Journal of Bone and Mineral Research 200015 2276-2283. (doi:10.1359/jbmr.2000. 15.11.2276)

34 Jensen C, Holloway L, Block G, Spiller G, Gildengorin G, Gunderson E, Butterfield $\mathrm{G} \&$ Marcus R. Long-term effects of nutrient intervention on markers of bone remodeling and calciotropic hormones in late-postmenopausal women. American Journal of Clinical Nutrition 2002 75 1114-1120

35 Kenny A, Prestwood K, Biskup B, Robbins B, Zayas E, Kleppinger A, Burleson J \& Raisz L. Comparison of the effects of calcium loading with calcium citrate or calcium carbonate on bone turnover in postmenopausal women. Osteoporosis International 200415 290-294. (doi:10.1007/s00198-003-1567-0)

36 Kenny AM, Biskup B, Robbins B, Marcela J \& Burleson JA. Effects of vitamin D supplementation on strength, physical function, and health perception in older, community-dwelling men. Journal of the American Geriatrics Society 200351 1762-1767. (doi:10.1046/j.1532-5415.2003. 51561.x

37 Komulainen MH, Kröger H, Tuppurainen MT, Heikkinen A-M, Alhava E, Honkanen R \& Saarikoski S. HRT and Vit D in prevention of non-vertebral fractures in postmenopausal women; a 5 year randomized trial. Maturitas 199831 45-54. (doi:10.1016/S03785122(98)00085-1)
38 Krieg MA, Jacquet AF, Bremgartner M, Cuttelod S, Thiébaud D \& Burckhardt P. Effect of supplementation with vitamin D3 and calcium on quantitative ultrasound of bone in elderly institutionalized women: a longitudinal study. Osteoporosis International 19999 483-488. (doi:10.1007/s001980050265)

39 Lips P. Vitamin D deficiency and osteoporosis: the role of vitamin D deficiency and treatment with vitamin D and analogues in the prevention of osteoporosis-related fractures. European Journal of Clinical Investigation 199626 436-442. (doi:10.1046/j.1365-2362. 1996.176290.x)

40 Lips P, Wiersinga A, van Ginkel FC, Jongen MJ, Netelenbos JC, Hackeng WH, Delmas PD \& van der Vijgh WJ. The effect of vitamin D supplementation on vitamin D status and parathyroid function in elderly subjects. Journal of Clinical Endocrinology and Metabolism 1988 67 644-650. (doi:10.1210/jcem-67-4-644)

41 Lovell GA, Byth JL, Craswell PW, Phillips PA \& Thomas MJ. The influence of sunlight or dietary vitamin D on plasma 25-hydroxyvitamin $\mathrm{D}$ in institutionalized elderly patients in a sub-tropical climate. Journal of Human Nutrition and Dietetics 19881 163-170. (doi:10.1111/ j.1365-277X.1988.tb00185.x)

42 Meier C, Woitge HW, Witte K, Lemmer B \& Seibel MJ. Supplementation with oral vitamin D3 and calcium during winter prevents seasonal bone loss: a randomized controlled open-label prospective trial. Journal of Bone and Mineral Research 200419 1221-1230. (doi:10.1359/ JBMR.040511)

43 Ooms ME, Roos JC, Bezemer PD, van der Vijgh WJ, Bouter LM \& Lips P. Prevention of bone loss by vitamin D supplementation in elderly women: a randomized double-blind trial. Journal of Clinical Endocrinology and Metabolism 199580 1052-1058. (doi:10.1210/ jc.80.4.1052)

44 Orwoll ES, Weigel RM, Oviatt SK, McClung MR \& Deftos LJ. Calcium and cholecalciferol: effects of small supplements in normal men. American Journal of Clinical Nutrition 198848 127-130.

45 Patel R, Collins D, Bullock S, Swaminathan R, Blake GM \& Fogelman I. The effect of season and vitamin D supplementation on bone mineral density in healthy women: a double-masked crossover study. Osteoporosis International 2001 12 319-325. (doi:10.1007/s001980170122)

46 Riis B, Christiansen C \& Rodbro P. The effect of different vitamin D treatments on serum vitamin D levels in early postmenopausal women. Acta Vitaminologica et Enzymologica 19846 77-82.

47 Schaafsma A, van Doormaal JJ, Muskiet FA, Hofstede GJ, Pakan I \& van der Veer E. Positive effects of a chicken eggshell powder-enriched vitamin-mineral supplement on femoral neck bone mineral density in healthy late post-menopausal Dutch women. British Journal of Nutrition 200287 267-275.

48 Schaafsma A, Muskiet FA, Storm H, Hofstede GJ, Pakan I \& Van der Veer E. Vitamin D(3) and vitamin K(1) supplementation of Dutch postmenopausal women with normal and low bone mineral densities: effects on serum 25-hydroxyvitamin D and carboxylated osteocalcin. European Journal of Clinical Nutrition 200054 626-631. (doi:10.1038/ sj.ejcn.1601065

49 Sebert JL, Garabedian M, Chauvenet M, Maamer M, Agbomson F \& Brazier M. Evaluation of a new solid formulation of calcium and vitamin D in institutionalized elderly subjects. A randomized comparative trial versus separate administration of both constituents. Revue du Rhumatisme 199562 288-294.

50 Sorva A, Risteli J, Risteli L, Valimaki M \& Tilvis R. Effects of vitamin D and calcium on markers of bone metabolism in geriatric patients with low serum 25-hydroxyvitamin D levels. Calcified Tissue International 199149 (Suppl) S88-S89. (doi:10.1007/BF02555103)

51 Vieth R, Kimball S, Hu A \& Walfish PG. Randomized comparison of the effects of the vitamin D3 adequate intake versus $100 \mu \mathrm{g}$ (4000 IU) per day on biochemical responses and the wellbeing of patients. Nutrition Journal 20043 8. (doi:10.1186/1475-2891-3-8)

52 Zhu K, Devine A, Dick IM, Wilson SG \& Prince RL. Effects of calcium and vitamin $\mathrm{D}$ supplementation on hip bone mineral density and

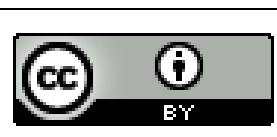

This work is licensed under a Creative Commons Attribution 3.0 Unported License. 
calcium-related analytes in elderly ambulatory Australian women: a five-year randomized controlled trial. Journal of Clinical Endocrinology and Metabolism 200893 743-749. (doi:10.1210/jc. 2007-1466)

53 Byrne PM, Freaney R \& McKenna MJ. Vitamin D supplementation in the elderly: review of safety and effectiveness of different regimes. Calcified Tissue International 199556 518-520. (doi:10.1007/ BF00298580)

54 Bidar SS, Bours S, Geusens P \& Van den Bergh J. The influence of vitamin D supplementation on mean changes in serum $25(\mathrm{OH}) \mathrm{D}$ : a meta-analysis. Journal of Bone and Mineral Research 201227 (Suppl 1) S331 (Abstr)

55 Autier P, Gandini S \& Mullie P. A systematic review: influence of vitamin D supplementation on serum 25-hydroxyvitamin D concentration. Journal of Clinical Endocrinology and Metabolism 201297 2606-2613. (doi:10.1210/jc.2012-1238)

56 Durup D, Jorgensen HL, Christensen J, Schwarz P, Heegaard AM \& Lind B. A reverse J-shaped association of all-cause mortality with serum 25-hydroxyvitamin D in general practice: the CopD study. Journal of Clinical Endocrinology and Metabolism 201297 2644-2652. (doi:10.1210/ jc.2012-1176)

57 McCarthy RA, McKenna MJ, Oyefeso O, Uduma O, Murray BF, Brady JJ, Kilbane MT, Murphy JF, Twomey A, O'Donnell CP et al. Vitamin D nutritional status in preterm infants and response to supplementation. British Journal of Nutrition 2012 [in press].

58 Vanstone MB, Oberfield SE, Shader L, Ardeshirpour L \& Carpenter TO. Hypercalcemia in children receiving pharmacologic doses of vitamin D. Pediatrics 2012129 e1060-e1063. (doi:10.1542/peds.2011-1663)

59 Schlingmann KP, Kaufmann M, Weber S, Irwin A, Goos C, John U, Misselwitz J, Klaus G, Kuwertz-Broking E, Fehrenbach $\mathrm{H}$ et al. Mutations in CYP24A1 and idiopathic infantile hypercalcemia. New England Journal of Medicine 2011365 410-421. (doi:10.1056/NEJMoa1103864)

60 Meyer HE, Robsahm TE, Bjorge T, Brustad M \& Blomhoff R. Vitamin D season, and risk of prostate cancer: a nested case-control study within Norwegian health studies. American Journal of Clinical Nutrition 201397 147-154. (doi:10.3945/ajcn.112..1007/BF02554828)

61 Chung M, Lee J, Terasawa T, Lau J \& Trikalinos TA. Vitamin D with or without calcium supplementation for prevention of cancer and fractures: an updated meta-analysis for the U.S. Preventive Services Task Force. Annals of Internal Medicine 2011155 827-838.

62 Moyer VA. Vitamin D and calcium supplementation to prevent fractures in adults: U.S. Preventive Services Task Force Recommendation Statement. Annals of Internal Medicine 2013 [in press].

63 Institute of Medicine. In Dietary Reference Intakes for Calcium, Phosphorus, Magnesium, Vitamin D and Fluoride. pp 250-287. Washington, DC: National Academies Press, 1997.
Received in final form 10 March 2013

Accepted 12 March 2013 http://www.endocrineconnections.org DOI: 10.1530/EC-13-0008
(C) 2013 The authors Published by Bioscientifica Ltd

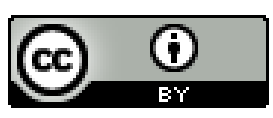

This work is licensed under a Creative Commons Attribution 3.0 Unported License. 